\title{
Epidemiological and molecular analysis of human norovirus infections in Taiwan during 2011 and 2012
}

\author{
Meng-Bin Tang ${ }^{1}$, Chien-Hsien Chen ${ }^{2}$, Shou-Chien Chen ${ }^{3,4}$, Yu-Ching Chou ${ }^{5}$ and Chia-Peng Yu²*
}

\begin{abstract}
Background: The human norovirus (NV) circulates worldwide and is a major cause of epidemics, which have increased in Taiwan since 2002. NV in acute gastroenteritis (AGE) and non-acute gastroenteritis (asymptomatic) patients, including children and adults, have not been previously examined in Taiwan; therefore, we examined the epidemiology and phylogeny of NV in AGE and asymptomatic patients of all ages.

Methods: 253 stool samples were collected from August 2011 to July 2012 (including 155 AGE and 98 asymptomatic samples in Taiwan) and analyzed using reverse transcription-polymerase chain reaction (RT-PCR) for NV. Primers targeting the RNA-polymerase gene were used for RT-PCR to allow DNA sequencing of Taiwan NV strains and phylogenetic analyses.

Results: NV was detected in 24 (9.5\%) of 253 stool specimens using RT-PCR. NV was isolated from all age groups (1 to 86 y) and those NV-positive samples were major identified from inpatients (79.2\%, 19/24). Statistical analysis showed that the NV infectious rate of AGE patients was statistically significant $(P<0.05)$ for age, season and water type, respectively. Phylogenetic analyses of the RdRp region sequence showed that $24 \mathrm{NV}$ isolates belonged to Genogroup II Genotype 4 (GII.4). They were closely related to the epidemic strain in Taiwan in 2006, the Gll.4-2006b pandemic strain in 2006, and the Gll.4-New Orleans strain in 2010.
\end{abstract}

Conclusion: This study is the first to examine NV in sporadic AGE and asymptomatic patients in Taiwan. Furthermore, epidemic strains of isolated Gll.4 were predominant in Taiwan during 2011 and 2012.

Keywords: Human norovirus, Molecular epidemiology, RT-PCR, Taiwan

\section{Background}

Viral gastroenteritis is a major threat with high morbidity and mortality, especially in children, elderly people, and immunocompromised people in developing and developed countries. It is estimated that viral gastroenteritis is the cause of $30 \%-40 \%$ of infectious cases in developed countries [1]. Human noroviruses (NV) are the leading cause of epidemic acute non-bacterial gastroenteritis worldwide. Taiwan has experienced a substantial increase in NV outbreaks and sporadic records since 2002 [2]. Enzyme-linked immunosorbent assays showed that $20 \%$ of pediatric viral gastroenteritis cases were caused by NV from 2004 to 2005 [3]. Four NV outbreaks

\footnotetext{
* Correspondence: yu6641@gmail.com

${ }^{2}$ Department of Bioengineering, Tatung University, Taipei, Taiwan Full list of author information is available at the end of the article
}

occurred in a psychiatric care center, and the mean incidence rate of NV gastroenteritis in hospitalized patients during these outbreaks was $12.7 \%$ from 2005 to 2007 [4].

NV belongs to the Caliciviridae family and has a singlestranded RNA genome of 7.5-7.7 kb. They are currently classified into 5 genogroups (GI to GV) [5], and only NV GI, GII, and GIV have been associated with human gastroenteritis [6]. NV is spread through a number of pathways with the occurrence of both fecal-oral and vomit-oral transmission. Direct person-to-person transmission is a primary mode of transmission in most outbreaks [7] and sporadic diseases [8]. Furthermore, NV disease outbreaks are reported year-round. They peak during months with cold weather and temperate climates [9].

NV sporadic cases involving children have been reported in Taiwan [10-13]. However, data on the molecular 
epidemiology (including epidemic genotyping, ages, and seasonality) of NV infection in acute gastroenteritis (AGE) and non-acute gastroenteritis (asymptomatic) patients in Taiwan are limited. The objectives of the study were as follows: to determine the AGE and asymptomatic infection rates of NV among hospital patients; to examine the association of patients age and of infection seasons with the NV infection rates; to analyze the NV genotypes by RTPCR and sequencing methods.

\section{Methods}

\section{Case definition}

AGE patients were defined as patients with clinical diarrhea ( $\geqq 3$ loose stools within a $24 \mathrm{~h}$ period), which may be accompanied by abdominal pain, fever, nausea, and vomiting. Asymptomatic patients were defined as patients undergoing routine medical examinations without symptoms of clinical diarrhea.

\section{Specimen collection}

This study was approved by the Human Subject Research Ethics Committee of the Wei-Gong Memorial Hospital and the approval number was 100003. Informed written consent was obtained from adult participants and parents of minors. This study was conducted from August 2011 to July 2012 at Wei-Gong Memorial Hospital in Taiwan. The stools of 253 patients (155 AGE and 98 asymptomatic patients) were collected. The stool samples were stored at $-20^{\circ} \mathrm{C}$ before transfer on ice blocks to the Department of Bioengineering, Tatung University, where they were stored at $-70^{\circ} \mathrm{C}$. The samples were frozen $\left(-70^{\circ} \mathrm{C}\right)$ before or after initial analysis as fecal suspensions. The samples were examined for the presence of NV using RT-PCR before storage in a balanced salt solution at $10 \%$ suspensions at $-70^{\circ} \mathrm{C}$ until use.

\section{Nucleic acid extraction and RT-PCR}

Nucleic acid was extracted using a viral nucleic acid extraction kit (Geneaid, Taiwan) from $200 \mu \mathrm{L}$ of $10 \%$ fecal suspension to a final volume of $50 \mu \mathrm{L}$ of RNase-free $\mathrm{H}_{2} \mathrm{O}$. RT-PCR for NV was performed using $10 \mu \mathrm{L}$ nucleic acid with $10 \mu \mathrm{L}$ of RT-PCR mix (Qiagen, Taiwan) containing the RT-PCR mix for NV contained $0.5 \mu \mathrm{L}$ $(10 \mu \mathrm{M})$ of JV12 (5'ATACCACTATGATGCAGATTA-3', nucleotides location 4552-4572) and JV13 (5'-TCATC ATCACCATAGAAAGAG-3', nucleotides location 48784858) primers [14], a $4 \mu \mathrm{L}$ buffer, $0.4 \mu \mathrm{L}(10 \mathrm{mM})$ dNTPs, $3.8 \mu \mathrm{L} \mathrm{H} \mathrm{H}_{2} \mathrm{O}$, and $0.8 \mu \mathrm{L}(1.25 \mathrm{U} / \mu \mathrm{L})$ of enzyme mix. The thermal conditions for NV-specific one-step RT-PCR were $50^{\circ} \mathrm{C}$ for $30 \mathrm{~min}$ and $95^{\circ} \mathrm{C}$ for $15 \mathrm{~min}, 40$ cycles at $94^{\circ} \mathrm{C}$ for $30 \mathrm{~s}, 37^{\circ} \mathrm{C}$ for $1 \mathrm{~min}$, and $72^{\circ} \mathrm{C}$ for $1 \mathrm{~min}$, followed by a final extension of $72^{\circ} \mathrm{C}$ for $10 \mathrm{~min}$. The amplicons were analyzed in $2 \%$ agarose gel electrophoresis at $100 \mathrm{~V}$ for $30 \mathrm{~min}$ and visualized under UV light after ethidium bromide staining. Positive PCR products were stored at $-20^{\circ} \mathrm{C}$. All NV positive samples were subjected to sequence and phylogenetic analyses.

\section{Sequence and phylogenetic analyses}

NVs were identified based on nucleotide sequences of the RNA-dependent RNA polymerase (RdRp) region, which comprised $327 \mathrm{bp}$ for the positive control. All NV PCR product sequences were analyzed using the basic local alignment search tool (BLAST) and DNAMAN software. Phylogenetic trees with 1000 bootstrap replicates were generated using the neighbor-joining method by employing molecular evolutionary genetics analysis (MEGA), version 5.0. Reference strains were downloaded from the GenBank. Only bootstrap values $>65$ were considered significant.

\section{Statistical analysis}

For categorical variables, the chi-square test was used to examine differences in proportions between groups. $P$ values $<0.05$ were considered statistically significant. Fisher's exact tests were used when the expected value for a cell was $<5$.

\section{Results}

\section{Study population}

During the study period, 253 patients (including children and adults) comprising 136 (53.8\%) males were enrolled. Among them, 155 (61.3\%) were AGE patients. The samples (including 53 obtained from outpatients, 6 from emergency unit, and 194 from inpatients) were collected and screened for NV. All sample characteristics by the enrolment site are shown in Table 1.

\section{NV positive rates and clinical features}

NV was detected in 24 (9.5\%) of all samples, 17 (11\%) in AGE patients, and 7 (7.1\%) in asymptomatic patients. The clinical feature of NV that detected in AGE and asymptomatic patients, were fever, vomiting, and abdominal pain (Table 1). AGE patients with NV-positive were significantly higher in fever and in vomiting than with NVnegative (Table 1). Clinical symptoms of NV-positive AGE include fever $(61.1 \%, 11 / 18)$, vomiting $(42.1 \%, 8 / 19)$, watery stool $(42.1 \%, 8 / 19)$, and abdominal pain $(50 \%, 9 /$ 18) (Table 2).

\section{Epidemiological features}

AGE patients with NV-positive were more likely to drink spring water than NV-negative patients $(23.5 \%$, $4 / 17$ versus $5.1 \%, 7 / 138$ ) (Table 1 ). NV infections were identified in AGE patients of all ages (1 to $86 \mathrm{y}$ ) (Table 2). NV was detected more often in AGE patients less than 10 years old $(52.9 \%, 9 / 17$ versus $16.7 \%$, $23 / 138)$, and those greater than 40 years old $(29.4 \%, 5 /$ 
Table 1 Epidemiological and clinical features by examine NV in AGE, asymptomatic patients

\begin{tabular}{|c|c|c|c|c|c|c|c|c|}
\hline \multirow[b]{3}{*}{ Parameter } & \multicolumn{2}{|c|}{ AGE patients $(n=155)$} & \multirow[b]{3}{*}{$P^{\mathrm{a}}$} & \multirow[b]{3}{*}{$O R^{d}$} & \multirow[b]{3}{*}{$95 \% \mathrm{Cl}^{\mathrm{d}}$} & \multicolumn{2}{|c|}{ Asymptomatic patients $(n=98)$} & \multirow[b]{3}{*}{$P^{\mathrm{b}}$} \\
\hline & NV & Negative & & & & NV & Negative & \\
\hline & $(n=17)$ & $(n=138)$ & & & & $(n=7)$ & $(n=91)$ & \\
\hline Detection rate (\%) & 11 & - & & & & 7.1 & - & \\
\hline Sex (male: female) & $10: 7$ & 74:64 & & & & $5: 2$ & 47:44 & \\
\hline \multicolumn{9}{|l|}{ Setting } \\
\hline Outpatient $(38,15)^{\mathbf{c}}$ & $2(11.8)$ & $36(26.1)$ & - & - & - & $3(42.8)$ & $12(13.2)$ & - \\
\hline Emergency $(6,0)^{c}$ & - & $6(4.3)$ & - & - & - & - & - & - \\
\hline Inpatient $(111,83)^{\mathbf{c}}$ & $15(88.2)$ & $96(69.6)$ & - & - & - & $4(57.2)$ & $79(86.8)$ & - \\
\hline \multicolumn{9}{|l|}{ Age } \\
\hline$<10$ & $9(52.9)$ & $23(16.7)$ & 0.002 & 5.6 & $2.0-16.1$ & $1(14.3)$ & $4(4.4)$ & - \\
\hline $10-40$ & $3(17.7)$ & $28(20.3)$ & - & - & & $2(28.6)$ & $5(5.5)$ & - \\
\hline$>40$ & $5(29.4)$ & $87(63.0)$ & 0.016 & 0.2 & $0.1-0.7$ & $4(57.1)$ & $82(90.1)$ & - \\
\hline \multicolumn{9}{|l|}{ Season } \\
\hline Spring & $3(17.6)$ & $54(39.1)$ & - & - & - & - & $23(25.3)$ & - \\
\hline Summer & $2(11.8)$ & $42(30.4)$ & - & - & - & $4(57.1)$ & $45(49.4)$ & - \\
\hline Fall & $2(11.8)$ & $10(7.3)$ & - & - & - & - & $10(11.0)$ & - \\
\hline Winter & $10(58.8)$ & $32(23.2)$ & 0.004 & 4.7 & $1.7-13.4$ & $3(42.9)$ & $13(14.3)$ & - \\
\hline \multicolumn{9}{|l|}{ Water type } \\
\hline Tap water & $12(70.6)$ & $118(85.5)$ & - & - & - & $6(85.7)$ & $81(89.0)$ & - \\
\hline Underground water & - & $2(1.4)$ & - & - & - & - & - & - \\
\hline Spring water & $4(23.5)$ & $7(5.1)$ & 0.022 & 5.8 & $1.5-22.3$ & - & $2(2.2)$ & - \\
\hline Miss data & $1(5.9)$ & $11(8.0)$ & - & - & - & $1(14.3)$ & $8(8.8)$ & - \\
\hline Fever $>38^{\circ} \mathrm{C}(\%)$ & & & & - & - & & & \\
\hline Yes & $9(52.9)$ & $47(34.1)$ & - & 2.5 & $0.9-7.1$ & $2(28.6)$ & $21(23.1)$ & - \\
\hline No & $7(41.2)$ & $91(65.9)$ & - & - & - & $5(71.4)$ & 70(76.9) & - \\
\hline Miss data & $1(5.9)$ & - & - & - & - & - & - & - \\
\hline \multicolumn{9}{|l|}{ Vomiting } \\
\hline Yes & $7(41.2)$ & $28(20.3)$ & - & 2.7 & $0.9-7.7$ & - & $6(6.6)$ & - \\
\hline No & $10(58.8)$ & 108(78.3) & - & - & - & $7(100)$ & $85(93.4)$ & - \\
\hline Miss data & - & $2(1.4)$ & - & - & - & - & - & - \\
\hline \multicolumn{9}{|l|}{ Stool type } \\
\hline Watery & $8(47.1)$ & $49(35.5)$ & - & - & - & - & $1(1.1)$ & - \\
\hline Bloody & $1(5.8)$ & $18(13.0)$ & - & - & - & - & $3(3.3)$ & - \\
\hline Non-watery, non-bloody & $8(47.1)$ & $71(51.5)$ & - & - & - & $7(100)$ & $87(95.6)$ & - \\
\hline \multicolumn{9}{|l|}{ Abdominal pain } \\
\hline Yes & $9(52.9)$ & $84(60.9)$ & - & - & - & - & 19(20.9) & - \\
\hline No & $7(41.2)$ & $52(37.7)$ & - & - & - & $7(100)$ & $72(79.1)$ & - \\
\hline Miss data & $1(5.9)$ & $2(1.4)$ & - & - & - & - & - & - \\
\hline
\end{tabular}


Table 2 Characteristics of NV-associated with AGE and asymptomatic patients

\begin{tabular}{|c|c|c|c|c|c|c|c|c|}
\hline No. & Years & Location & Genotype & AGE & Fever & Vomiting & Stool & Abdominal pain \\
\hline 2 & 13 & Inpatient & Gll.4 & $Y^{a}$ & Y & Y & $\mathrm{Nn}^{\mathrm{b}}$ & Miss \\
\hline 10 & 5 & Inpatient & Gll.4 & Y & Y & $\mathrm{N}$ & $\mathrm{Nn}$ & $\mathrm{N}$ \\
\hline 14 & 40 & Inpatient & Gll.4 & $N^{a}$ & $\mathrm{~N}$ & $\mathrm{~N}$ & $\mathrm{Nn}$ & $\mathrm{N}$ \\
\hline 22 & 22 & Outpatient & Gll.4 & Y & $\mathrm{N}$ & $\mathrm{N}$ & Watery & $\mathrm{N}$ \\
\hline 27 & 7 & Inpatient & Gll.4 & Y & Y & Y & Watery & Y \\
\hline 31 & 1 & Inpatient & Gll.4 & Y & Y & $\mathrm{N}$ & $\mathrm{Nn}$ & $\mathrm{N}$ \\
\hline 37 & 46 & Outpatient & Gll.4 & N & $N$ & N & $\mathrm{Nn}$ & N \\
\hline 40 & 6 & Inpatient & Gll.4 & Y & Y & Y & Watery & Y \\
\hline 41 & 31 & Outpatient & Gll.4 & $N$ & $N$ & $\mathrm{~N}$ & $\mathrm{Nn}$ & $\mathrm{N}$ \\
\hline 44 & 50 & Inpatient & Gll.4 & Y & N & $\mathrm{N}$ & Watery & Y \\
\hline 45 & 2 & Inpatient & Gll.4 & Y & Y & $\mathrm{N}$ & Watery & $\mathrm{N}$ \\
\hline 49 & 86 & Inpatient & Gll .4 & Y & Y & $\mathrm{N}$ & $\mathrm{Nn}$ & Y \\
\hline 51 & 68 & Inpatient & Gll.4 & Y & N & $\mathrm{N}$ & $\mathrm{Nn}$ & Y \\
\hline 54 & 17 & Outpatient & Gll.4 & Y & $N$ & Y & $\mathrm{Nn}$ & $\mathrm{N}$ \\
\hline 56 & 1 & Inpatient & Gll.4 & Y & Y & $\mathrm{N}$ & Watery & $\mathrm{N}$ \\
\hline 84 & 71 & Inpatient & Gll .4 & Y & Miss & $N$ & $\mathrm{Nn}$ & $\mathrm{N}$ \\
\hline 107 & 2 & Inpatient & Gll.4 & Y & $\mathrm{N}$ & Y & Watery & Y \\
\hline 122 & 2 & Inpatient & Gll.4 & Y & Y & Y & Watery & Y \\
\hline 171 & 1 & Inpatient & Gll.4 & Y & $N$ & Y & $\mathrm{Nn}$ & Y \\
\hline 183 & 75 & Inpatient & Gll.4 & N & Y & $\mathrm{N}$ & $\mathrm{Nn}$ & $\mathrm{N}$ \\
\hline 184 & 82 & Inpatient & Gll.4 & Y & $N$ & Y & Bloody & Y \\
\hline 191 & 66 & Inpatient & Gll.4 & $N$ & $N$ & $N$ & $\mathrm{Nn}$ & $\mathrm{N}$ \\
\hline 193 & 1 & Inpatient & Gll.4 & N & Y & $N$ & $\mathrm{Nn}$ & $\mathrm{N}$ \\
\hline 203 & 75 & Outpatient & Gll.4 & $\mathrm{N}$ & $\mathrm{N}$ & $\mathrm{N}$ & $\mathrm{Nn}$ & $\mathrm{N}$ \\
\hline
\end{tabular}

a: $Y$ Yes, $N$ No.

b:Nn Non-watery, non-bloody stool.

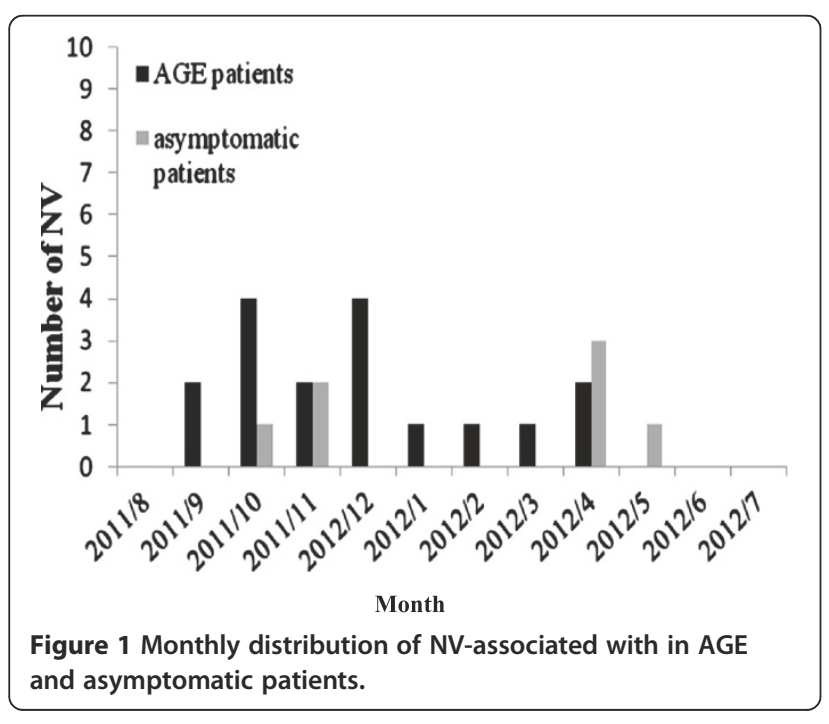

17 versus 63\%, 87/138) (Table 1 and Figure 1). However, asymptomatic patients with NV-positive were identified both from $<2$ and from $>20$ years old. Those $\mathrm{NV}$-positive samples were major identified from inpatients $(79.2 \%, 19 / 24)$ (Table 2). NV infections were identified throughout the year (highest incidence in December, followed by October) among patients and controls. NV was detected in AGE patients more often in the winter than in the other seasons (Table 1 and Figure 2).

\section{Phylogenetic analyses}

Twenty-four NVs that were identified and sequenced belonged to the NV Genogroup II.4 (GII.4). Three GII.4 variants (GII.4-2006b, GII.4-2010tw, and GII.4-New Orleans variants) were identified, as shown in Figure 3.

\section{Discussion}

NVs are the leading cause of AGE among people [15]. $\mathrm{NV}$ is associated with $6 \%-25 \%$ of AGE patients worldwide [16-20]. Previous studies have indicated that the 


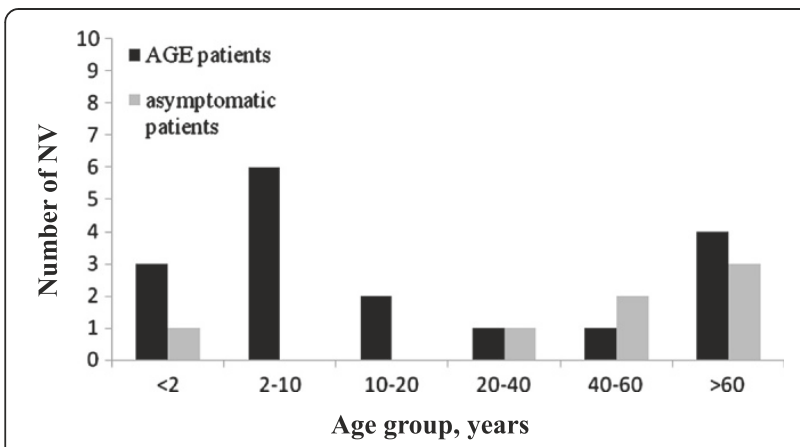

Figure 2 Age group distribution of NV-associated with AGE and asymptomatic patients.

NV positive rate differs significantly between AGE (16.1\%) and asymptomatic (5.2\%) [21]. The NV positive rate (11\%) among AGE patients in this study was similar to those in Taiwan (10.5\%) [22] and Australia (11.4\%) [23]. In this study, the NV positive detection rate although was so low, but its prevalence rate was in accordance with other reports about the recent Taiwan situation (2007 prevalence of $8.2 \%, 2010$ prevalence of $14.6 \%)[10,12]$. The major reason to explain why NV positive rate so low was the lower gastroenteritis fecal samples. So we will continue to collect more gastroenteritis fecal samples in the next year. Furthermore, the NV positive rate $(7.1 \%)$ among asymptomatic patients was similar to that in India (7.5\%) [24]. Therefore, this study shows that the predominance of NV infections in Taiwan is a pandemic and may indicate the circulation of this strain in this region.

A previous study indicated that GII.4 strains of NV were dominant in AGE and asymptomatic patients during a recent hospital outbreak [25]. This result is similar to that obtained in this study. The GII.4 strains are a major cause of sporadic occurrences of AGE. Although NV GII.4 strains are widespread, they do not always cause AGE, which may account for the increased number of infections through asymptomatic transmission routes [26]. Furthermore, the population usually includes asymptomatic carriers of NV related to the occurrence of NV outbreaks [27]. Therefore, commonly occurring NV infections may result from multiple routes of transmission, especially for asymptomatic patients with NV pathways.

A previous study [28] indicated that the NV positive rate of AGE patients differs significantly between inpatients (16.7\%) and outpatients (9.2\%). The NV positive rate for AGE and asymptomatic patients that from inpatients and outpatients (Table 1) was similar to that of recent studies [21,24,29-35]. Therefore, in this study, the result appeared that AGE patients with NV-positive from inpatients were higher than from outpatients.

Among all NV GII.4 samples in this study, those samples were inpatients (79.2\%) and outpatients (20.8\%), respectively. Similar to a previous study [36], the analysis indicated that severe outcomes are associated with $\mathrm{NV}$ GII.4 infections. Therefore, epidemic strains of isolated GII.4 may cause severe clinical symptoms, and patients may require hospitalization.

NV in AGE patients was significantly associated with the consumption of spring water [37]. Previous studies are consistent with our observation that AGE-related $\mathrm{NV}$ infections are significantly related to the consumption of spring water. Similar to a previous study, the analysis indicated that the GII strain was associated with spring water $(\mathrm{OR}=3.8)$. The consumption of spring water is a risk factor and suspected transmission route. A previous study indicated that NV in AGE patients was significantly associated with clinical symptoms [38]. This was similar to our observation that AGE-related NV infections have marginal statistical significance related to the diagnosis of fever and vomiting. The analysis also indicated that the GII strain was associated with vomiting. Both fever and vomiting are risk factors and may be used by clinicians for the clinical diagnosis of acute gastroenteritis in patients.

$\mathrm{NV}$ is a leading cause of sporadic gastroenteritis in children and adults. It is a common cause of hospitalization for gastroenteritis, especially among vulnerable populations (young children and elderly people). Similar to the results of previous studies [39], AGE-related NV infections have statistical significance in patients aged $<10$ and $>40$ years old compared to other age groups. It indicated that young children and elderly people may be at risk of NV infection. In this study, patients aged 1 to 86 years were infected with $\mathrm{NV}$, indicating $\mathrm{NV}$ infections in all age groups. This indicated the predominance of NV infections in young children and elderly people, and may provide health authorities in Taiwan with control strategies to prevent person-to-person $\mathrm{NV}$ transmission.

Transmission of NV infections occurred year-round in most surveys, and a cold weather peak was observed in 11 of the 12 studies [9]. The detection rate of AGErelated NV infections is significantly greater during the winter compared to the other seasons [40,41]. This epidemiologic feature of NV has crucial implications regarding the mode of transmission and understanding the etiology of gastroenteritis in children and adults.

Human diseases are primarily caused by GI and GII NVs, and most outbreaks are caused by GII.4 strains [42]. The major pandemic genotype of NV in the world was GII.4, also include Taiwan [2,4]. New GII.4 strains have emerged every 2-3 y over the past decade, and have replaced previously predominant GII.4 strains $[43,44]$. In the previous study, it also indicated that NV GII was prevalent in some area only, without GI $[45,46]$. The similar result was appeared in this study. Furthermore, it had ever been proved that the major cause of one 


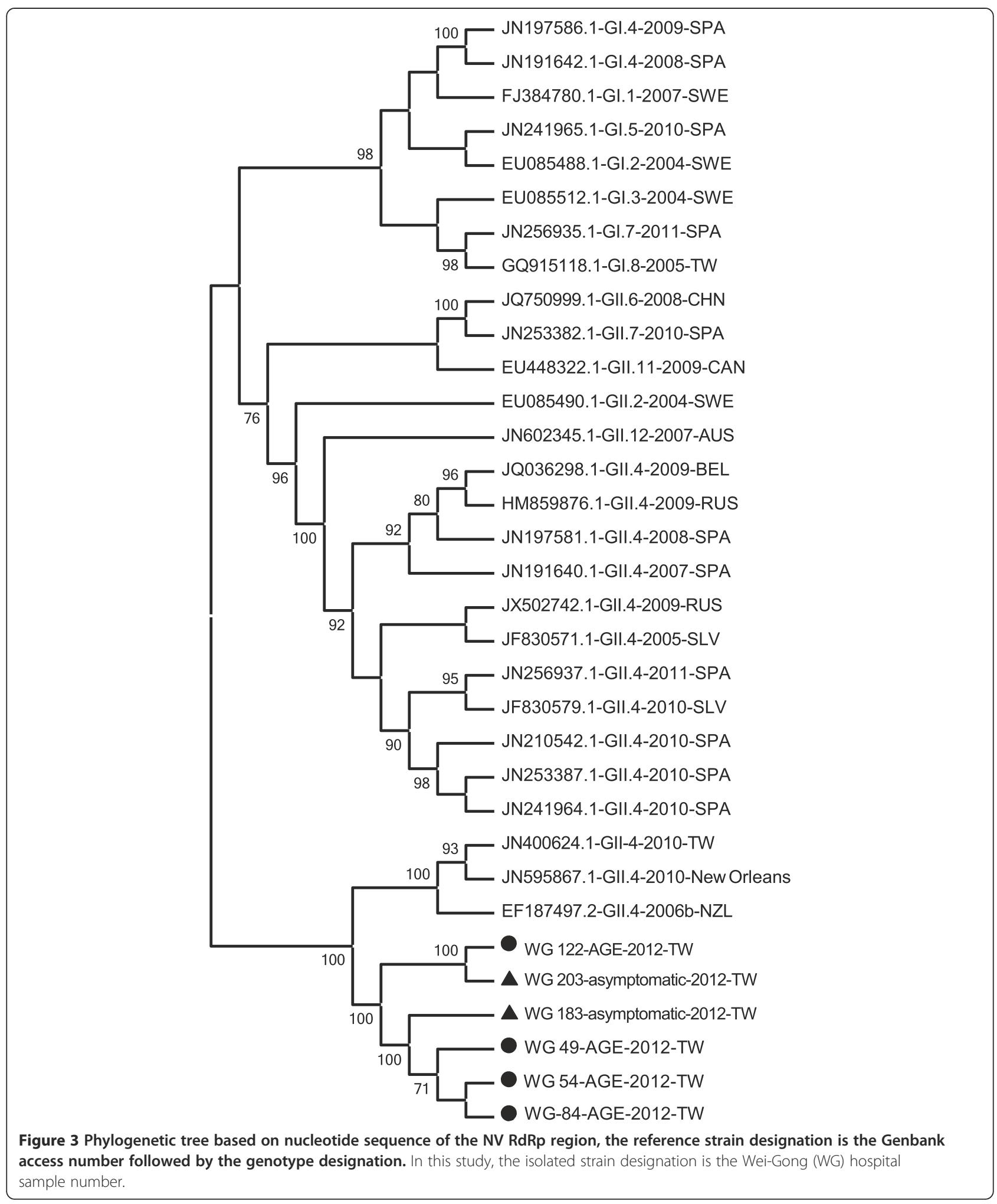

gastroenteritis outbreak in Taiwan was NV GII.4 (100\%, 31/31) only [47]. So we believed that only NV GII.4 did prevalent in the gastroenteritis patients in this study. NV GII.4-2006b was associated with sporadic gastroenteritis and was a globally circulating strain in several countries, including Japan, China, and Italy [48-50]. From previous reports $[48,49]$ and our result, it proved that AGE patients infected with NV GII.4-2006b could be more prevalent in 
younger children and in winter season. The total GII.4 isolate strains were closely related to the epidemic strain in Taiwan in 2006, the GII.4-2006b pandemic strain in 2006, and the strain in New Orleans (United States) in 2010. It is crucial to emphasize the existence of 2 variants of GII.4 (GII.4-2006b and GII.4-New Orleans) in Taiwan. NV GII.4 variant strains implicated in sporadic gastroenteritis worldwide also occurred in Taiwan, indicating global spread.

\section{Conclusion}

In summary, this study is the first to examine $\mathrm{NV}$ in sporadic AGE and asymptomatic patients in Taiwan. The results showed that the season and age distribution for NV-positive patients were similar to those in previous NV studies worldwide. Furthermore, our results indicated that epidemic strains of isolated GII.4 were predominant in Taiwan during 2011 and 2012. Systematic surveillance and evidence-based studies are required to determine the transmission pathways and spread of NV.

\section{Competing interests}

The authors declare that they have no competing interests.

\section{Authors' contributions}

MBT, SCC designed the epidemiological study, participated in its design and coordination. YCC performed the statistical analysis and participated in its design. SCC conceived of the study, and participated in its design and coordination and helped to draft the manuscript. CPY performed the laboratory test on human stool samples, carried out the molecular studies, participated in the sequence alignment and drafted and edited the manuscript. All authors read and approved the final manuscript.

\section{Acknowledgements}

This study was supported by grant WG 100-I-003 form the Wei-Gong Memorial Hospital and was supported in part by Tatung University grant (B101-S01-014). The authors are grateful to all our colleagues in the Department of Laboratory in Wei-Gong Memorial Hospital for their help in the collection of specimens. We also thanks Su-Chuen Lin, for assistance in data collection and entry.

\section{Author details}

'Department of Family Medicine, Wei-Gong Memorial Hospital, Toufen Township, Miaoli County, Taiwan. ${ }^{2}$ Department of Bioengineering, Tatung University, Taipei, Taiwan. ${ }^{3}$ General Education Center, Tatung University, Taipei, Taiwan. ${ }^{4}$ Department of Family Medicine, Da-Chien General Hospital, Miaoli City, Miaoli County, Taiwan. ${ }^{5}$ School of Public Health, National Defense Medical Center, Taipei, Taiwan.

Received: 23 March 2013 Accepted: 17 July 2013

Published: 22 July 2013

\section{References}

1. Hodges K, Gill R: Infectious diarrhea: cellular and molecular mechanisms. Gut Microbes 2010, 1(1):4-21.

2. Wu FT, Oka T, Katayama K, Wu HS, Donald Jiang DS, Miyamura T, Takeda N, Hansman GS: Genetic diversity of noroviruses in Taiwan between November 2004 and March 2005. Arch Virol 2006, 151(7):1319-1327.

3. Lin CY, Chiu NC, Lee HC, Chuang CK, Lin SP, Yeung CY: The emerging importance of norovirus as the etiology of pediatric gastroenteritis in Taipei. J Microbiol Immunol Infect 2010, 43(2):105-110.

4. Tseng CY, Chen CH, Su SC, Wu FT, Chen CC, Hsieh GY, Hung CH, Fung CP: Characteristics of norovirus gastroenteritis outbreaks in a psychiatric centre. Epidemiol Infect 2011, 139(2):275-285.
5. Patel MM, Hall AJ, Vinje J, Parashar UD: Noroviruses: a comprehensive review. J Clin Virol 2009, 44(1):1-8.

6. La Rosa G, Fontana S, Di Grazia A, laconelli M, Pourshaban M, Muscillo M: Molecular identification and genetic analysis of Norovirus genogroups I and II in water environments: comparative analysis of different reverse transcription-PCR assays. Appl Environ Microbiol 2007, 73(13):4152-4161.

7. Wikswo ME, Hall AJ, Centers for Disease C, Prevention: Outbreaks of acute gastroenteritis transmitted by person-to-person contact--United States, 2009-2010. MMWR Surveill Summ 2012, 61(9):1-12.

8. Phillips G, Tam CC, Rodrigues LC, Lopman B: Risk factors for symptomatic and asymptomatic norovirus infection in the community. Epidemiol Infect 2011, 139(11):1676-1686.

9. Mounts AW, Ando T, Koopmans M, Bresee JS, Noel J, Glass Rl: Cold weather seasonality of gastroenteritis associated with Norwalk-like viruses. J Infect Dis 2000, 181(Suppl 2):S284-287.

10. Yang SY, Hwang KP, Wu FT, Wu HS, Hsiung CA, Chang WC, Lin JS, Yang SC, Huang SL, Huang YC: Epidemiology and clinical peculiarities of norovirus and rotavirus infection in hospitalized young children with acute diarrhea in Taiwan, 2009. J Microbiol Immunol Infect 2010, 43(6):506-514.

11. Wu TC, Liu HH, Chen YJ, Tang RB, Hwang BT, Yuan HC: Comparison of clinical features of childhood norovirus and rotavirus gastroenteritis in Taiwan. J Chin Med Assoc 2008, 71(11):566-570.

12. Chen SY, Chang YC, Lee YS, Chao HC, Tsao KC, Lin TY, Ko TY, Tsai CN, Chiu $\mathrm{CH}$ : Molecular epidemiology and clinical manifestations of viral gastroenteritis in hospitalized pediatric patients in Northern Taiwan. J Clin Microbiol 2007, 45(6):2054-2057.

13. Chen SM, Ni YH, Chen HL, Chang MH: Microbial etiology of acute gastroenteritis in hospitalized children in Taiwan. J Formos Med Assoc 2006, 105(12):964-970.

14. Vinje J, Koopmans MP: Molecular detection and epidemiology of small round-structured viruses in outbreaks of gastroenteritis in the Netherlands. J Infect Dis 1996, 174(3):610-615.

15. Hall AJ, Rosenthal M, Gregoricus N, Greene SA, Ferguson J, Henao OL, Vinje J, Lopman BA, Parashar UD, Widdowson MA: Incidence of acute gastroenteritis and role of norovirus, Georgia, USA, 2004-2005. Emerg Infect Dis 2011, 17(8):1381-1388.

16. Kang $G$, Hale AD, Richards AF, Jesudason MV, Estes MK, Brown DW: Detection of 'Norwalk-like viruses' in Vellore, southern India. Trans $R$ Soc Trop Med Hyg 2000, 94(6):681-683.

17. Hansman GS, Doan LT, Kguyen TA, Okitsu S, Katayama K, Ogawa S, Natori K, Takeda N, Kato Y, Nishio O, et al: Detection of norovirus and sapovirus infection among children with gastroenteritis in Ho Chi Minh City, Vietnam. Arch Virol 2004, 149(9):1673-1688.

18. Hansman GS, Kuramitsu M, Yoshida H, Katayama K, Takeda N, Ushijima H, Surenkhand G, Gantolga D, Kuroiwa C: Viral gastroenteritis in Mongolian infants. Emerg Infect Dis 2005, 11(1):180-182.

19. Dove W, Cunliffe NA, Gondwe JS, Broadhead RL, Molyneux ME, Nakagomi $\mathrm{O}$, Hart CA: Detection and characterization of human caliciviruses in hospitalized children with acute gastroenteritis in Blantyre, Malawi. J Med Virol 2005, 77(4):522-527.

20. Liu C, Grillner L, Jonsson K, Linde A, Shen K, Lindell AT, Wirgart BZ, Johansen K: Identification of viral agents associated with diarrhea in young children during a winter season in Beijing, China. J Clin Virol 2006, 35(1):69-72.

21. de Wit MA, Koopmans MP, Kortbeek LM, Wannet WJ, Vinje J, van Leusden F, Bartelds Al, van Duynhoven YT: Sensor, a population-based cohort study on gastroenteritis in the Netherlands: incidence and etiology. Am J Epidemiol 2001, 154(7):666-674.

22. Yang LC, Chiang PC, Huang TH, Chi SF, Chiu YP, Lin CS, Chou YF, Hsu SC, Zhang $X S$, Huang $C G$, et al: Residents had an increasing risk of norovirus gastroenteritis infection than health care workers during an outbreak in a nursing home. J Am Med Dir Assoc 2010, 11(8):592-597.

23. Marshall JA, Hellard ME, Sinclair MI, Fairley CK, Cox BJ, Catton MG, Kelly H, Wright PJ: Incidence and characteristics of endemic Norwalk-like virusassociated gastroenteritis. J Med Virol 2003, 69(4):568-578.

24. Monica B, Ramani S, Banerjee I, Primrose B, Iturriza-Gomara M, Gallimore Cl, Brown DW MF, Moses PD, Gray JJ, et al: Human caliciviruses in symptomatic and asymptomatic infections in children in Vellore, South India. J Med Virol 2007, 79(5):544-551.

25. Gallimore Cl, Cubitt D, du Plessis N, Gray JJ: Asymptomatic and symptomatic excretion of noroviruses during a hospital outbreak of gastroenteritis. J Clin Microbiol 2004, 42(5):2271-2274. 
26. Ozawa K, Oka T, Takeda N, Hansman GS: Norovirus infections in symptomatic and asymptomatic food handlers in Japan. J Clin Microbiol 2007, 45(12):3996-4005.

27. Jeong AY, Jeong HS, Lee JS, Park YC, Lee SH, Hwang IG, Kim YJ, Kim YJ, Jo $M Y$, Jung $S$, et al: Occurrence of norovirus infections in asymptomatic food handlers in South Korea. J Clin Microbiol 2013, 51(2):598-600.

28. Lau CS, Wong DA, Tong LK, Lo JY, Ma AM, Cheng PK, Lim WW: High rate and changing molecular epidemiology pattern of norovirus infections in sporadic cases and outbreaks of gastroenteritis in Hong Kong. J Med Virol 2004, 73(1):113-117.

29. O'Ryan ML, Mamani N, Gaggero A, Avendano LF, Prieto S, Pena A, Jiang X, Matson DO: Human caliciviruses are a significant pathogen of acute sporadic diarrhea in children of Santiago, Chile. J Infect Dis 2000, 182(5):1519-1522

30. Parashar UD, Li JF, Cama R, DeZalia M, Monroe SS, Taylor DN, Figueroa D, Gilman RH, Glass Rl: Human caliciviruses as a cause of severe gastroenteritis in Peruvian children. J Infect Dis 2004, 190(6):1088-1092.

31. Oh DY, Gaedicke G, Schreier E: Viral agents of acute gastroenteritis in German children: prevalence and molecular diversity. J Med Virol 2003, 71(1):82-93

32. Amar CF, East CL, Gray J, Iturriza-Gomara M, Maclure EA, McLauchlin J: Detection by PCR of eight groups of enteric pathogens in 4,627 faecal samples: re-examination of the English case-control Infectious Intestinal Disease Study (1993-1996). Eur J Clin Microbiol Infect Dis 2007, 26(5):311-323.

33. Pang $\mathrm{XL}$, Joensuu J, Vesikari T: Human calicivirus-associated sporadic gastroenteritis in Finnish children less than two years of age followed prospectively during a rotavirus vaccine trial. Pediatr Infect Dis J 1999, 18(5):420-426

34. Bon F, Fascia P, Dauvergne M, Tenenbaum D, Planson H, Petion AM, Pothier $P$, Kohli E: Prevalence of group A rotavirus, human calicivirus, astrovirus, and adenovirus type 40 and 41 infections among children with acute gastroenteritis in Dijon, France. J Clin Microbiol 1999, 37(9):3055-3058.

35. de Wit MA, Koopmans MP, Kortbeek LM, van Leeuwen NJ, Bartelds Al, van Duynhoven YT: Gastroenteritis in sentinel general practices, The Netherlands. Emerg Infect Dis 2001, 7(1):82-91.

36. Desai R, Hembree CD, Handel A, Matthews JE, Dickey BW, McDonald S, Hall AJ, Parashar UD, Leon JS, Lopman B: Severe outcomes are associated with genogroup 2 genotype 4 norovirus outbreaks: a systematic literature review. Clin Infect Dis 2012, 55(2):189-193.

37. Shen JC, Lin JF, Gao J, Yao WT, Wen D, Liu GT, Han JK, Ma HL, Zhang LJ, Zhu BP: A norovirus-borne outbreak caused by contaminated bottled spring water in a school, Zhejiang province. Zhonghua Liu Xing Bing Xue Za Zhi 2011, 32(8):800-803.

38. Yori PP, Schwab K, Gilman RH, Nappier S, Portocarrero DV, Black RE, Olortegui MP, Hall ER, Moe C, Leon J, et al: Norovirus highly prevalent cause of endemic acute diarrhea in children in the peruvian Amazon. Pediatr Infect Dis J 2009, 28(9):844-847.

39. Patel MM, Widdowson MA, Glass Rl, Akazawa K, Vinje J, Parashar UD: Systematic literature review of role of noroviruses in sporadic gastroenteritis. Emerg Infect Dis 2008, 14(8):1224-1231.

40. Fankhauser RL, Monroe SS, Noel JS, Humphrey CD, Bresee JS, Parashar UD, Ando T, Glass Rl: Epidemiologic and molecular trends of "Norwalk-like viruses" associated with outbreaks of gastroenteritis in the United States. J Infect Dis 2002, 186(1):1-7.

41. Zheng DP, Widdowson MA, Glass RI, Vinje J: Molecular epidemiology of genogroup II-genotype 4 noroviruses in the United States between 1994 and 2006. J Clin Microbiol 2010, 48(1):168-177.

42. Johansen $K$, Mannerqvist $K$, Allard A, Andersson $Y$, Burman LG, Dillner $L$, Hedlund KO, Jonsson K, Kumlin U, Leitner T, et al: Norovirus strains belonging to the Gll.4 genotype dominate as a cause of nosocomial outbreaks of viral gastroenteritis in Sweden 1997--2005. Arrival of new variants is associated with large nation-wide epidemics. J Clin Virol 2008 42(2):129-134.

43. Centers for Disease C, Prevention: Notes from the field: emergence of New Norovirus Strain GIl.4 Sydney - United States, 2012. MMWR Morb Mortal Wkly Rep 2013, 62:55.

44. Sukhrie FH, Siebenga JJ, Beersma MF, Koopmans M: Chronic shedders as reservoir for nosocomial transmission of norovirus. J Clin Microbiol 2010, 48(11):4303-4305.

45. Altindis M, Banyai K, Kalayci R, Gulamber C, Koken R, Yoldas Y, Aykurt P, Martella V: Frequency of norovirus in stool samples from hospitalized children due to acute gastroenteritis in Anatolia, Turkey, 2006-2007. Scand J Infect Dis 2009, 41(9):685-688.

46. Ozkul AA, Kocazeybek BS, Turan N, Reuter G, Bostan K, Yilmaz A, Altan E, Uyunmaz G, Karakose AR, Muratoglu K, et al: Frequency and phylogeny of norovirus in diarrheic children in Istanbul, Turkey. J Clin Virol 2011, 51(3):160-164.

47. Lai CC, Wang YH, Wu CY, Hung CH, Jiang DD, Wu FT: A norovirus outbreak in a nursing home: norovirus shedding time associated with age. J Clin Virol 2013, 56(2):96-101.

48. Dey SK, Phan TG, Mizuguchi M, Okitsu S, Ushijima H: Genetic diversity and emergence of norovirus Gll/4-2006b in Japan during 2006-2007. Clin Lab 2011, 57(3-4):193-199.

49. Zhang S, Chen TH, Wang J, Dong C, Pan J, Moe C, Chen W, Yang L, Wang $X$, Tang $H$, et al: Symptomatic and asymptomatic infections of rotavirus, norovirus, and adenovirus among hospitalized children in Xi'an, China. J Med Virol 2011, 83(8):1476-1484.

50. Rimoldi SG, Stefani F, Pagani C, Chenal LL, Zanchetta N, Di Bartolo I, Lombardi A, Ruggeri FM, Di Lillo D, Zuccotti GV, et al: Epidemiological and clinical characteristics of pediatric gastroenteritis associated with new viral agents. Arch Virol 2011, 156(9):1583-1589.

doi:10.1186/1471-2334-13-338

Cite this article as: Tang et al:: Epidemiological and molecular analysis of human norovirus infections in Taiwan during 2011 and 2012. BMC Infectious Diseases 2013 13:338.

\section{Submit your next manuscript to BioMed Central and take full advantage of:}

- Convenient online submission

- Thorough peer review

- No space constraints or color figure charges

- Immediate publication on acceptance

- Inclusion in PubMed, CAS, Scopus and Google Scholar

- Research which is freely available for redistribution

Submit your manuscript at www.biomedcentral.com/submit
C Biomed Central 